\title{
The Legitimacy of Classical Dance Gagrag Ngayogyakarta
}

\author{
Y. Sumandiyo Hadi \\ Institut Seni Indonesia (ISI) Yogyakarta \\ Jalan Parangtritis Km 6,5, Sewon, Bantul Yogyakarta
}

\begin{abstract}
The aim of this article is to reveal the existence of classical dance style of Yogyakarta, since the government of Sultan Hamengku Buwono I, which began in 1756 until now in the era the government of Sultan Hamengku Buwono X. The legitimation of classical dance is considered as "Gagrag Ngayogyakarta". Furthermore, the dance is not only preserved in the palace, but living and growing outside the palace, and possible to be examined by the general public. The dance was first considered as a source of classical dance "Gagrag Ngayogyakarta", created by Sultan Hamengku Buwono I, i.e. Beksan Lawung Gagah, or Beksan Trunajaya, Wayang Wong or dance drama, and Bedaya dance. The three dances can be categorized as a sacred dance, in which the performances strongly related to traditional ceremonies or rituals. Three types of dance later was developed into other types of classical dance "Gagrag Ngayogyakarta", which is categorized as a secular dance for entertainment performance.
\end{abstract}

Keywords: Sultan Hamengku Buwono, classical dance, "gagrag", Yogyakarta style, legitimacy, sacred, ritual dance, secular dance

\section{INTRODUCTION}

Yogyakarta as one of the regions in the archipelago, which has various designations, including a student city, a tourism city, and a cultural city. As a cultural city, there are different types of artwork. One of them is a classical traditional dance, which is often called Beksa Klasik Gagrag Ngayogyakarta or Yogyakarta classical dance. This art has a strong historical root and becomes one of the tops of local culture that has been experiencing the process of re-inventing traditional culture.

This dance is often designated as adi luhung (noble) traditional classic art because it is a palace classical art product. The word "classic" comes from the Latin word "classisi". This term emerged since the medieval period that is the Roman Empire era, to categorize artwork, which has a high-quality value because it is produced by qualified artists from the upper-middle-class society, and not from the proletarians or low class. The term of tradition is a genre from the past, which is hereditary from one generation to generation. Moreover, there is an impression as if this concept is static, conservative, and resistant to change.

On the other hand, in many respects, the traditional performing arts are usually expressed through various forms as either sacred or ritual ceremony. Meanwhile, adi luhung (noble) means soft, elegant, complex as well as an art form that is considered to be completed (finesse). It has many rules, very binding one. The standard or the rules of Yogyakarta classical dance is guided by the nature of its form which is based on philosophical foundations called Kawruh Joged Mataram, that is the inspiration for a 
dancer consisting of four main elements called sawiji, greged, sengguh, and ora mingkuh (see Suryobrongto, 1981: 88-93), as well as the practical rule of aesthetic concepts called wiraga, wirama, and wirasa.

The sawiji element is understood as a full concentration or focusing his thoughts and actions without disturbing his soul. The greged element is understood as a spirit, a vigour, or inner dynamics, without being rude. The sengguh element is understood as an act of confidence (self-confidence), but without being arrogant. While ora mingkuh element is the spirit of abstinence by which maintaining self-discipline.

The practical guidance of the aesthetic concept of wiraga is concerned with the whole arrangement of motion relations in one unity of form so-called the figure of dance. The wirama relates to the time aspect, which manages the short or length of the phrase of dance movements in this case concerning the rhythm of motion, rhythm, tempo and its conformity with the rhythm of the dance accompaniment or gending accompaniment. Meanwhile, the sense of wirasa is related to the sense of motion or the purpose and content of a dance.

The process of creating a classic beksa gagrag Ngayogyakarta can be traced after Gianti agreement in 1755. The Mataram kingdom was split into two areas, with the agreement of Kasunanan Keraton Surakarta Hadiningrat, which was still ruled by Susuhunan Paku Buwono III. Meanwhile, his uncle Pangeran Mangkubumi then established Kasultanan Keraton Ngayogyakarta Hadiningrat, and then enthroned with the title of Sultan Hamengku Buwono I. In addition to the political agreement, the division of land, and its people, and other signs of power, the event also indirectly contains a cultural agreement, with agreements in the field of art and culture, dance, music, the art of dressing, and so forth. The two palaces still preserve the Mataraman cultural heritage; with each has own characteristic known as "Gagrag Surakarta" and "Gagrag Ngayogyakarta".

"Gagrag" is understood as "a style" which leads to a characteristic context, or a design, and a technique; whether involving a personal or individual style of the creator, as well as the socio-cultural features that underlie the presence of that form. In this case, Beksa Gagrag Ngayogyakarta means the style form and technique of dance movements, with a various cultural-social context of Yogyakarta.

It is estimated that forming the Beksa or Gagrag Ngayogyakarta is in conjunction with the establishment of Yogyakarta Sultanate around 1756. And it can be assumed that the dance was created by Sultan Hamengku Buwono I himself, who was regarded as the heir artist of Mataram dynasty, who has a big attention to the arts. Successively the dance of beksa gagrag Ngayogyakarta continues to be preserved and developed until now (under Sultan HB X government) and legitimized as a cultural heritage of the palace of Yogyakarta Sultanate (Y. Sumandiyo Hadi, 2013: 13-14).

The legitimacy of classical dance gagrag Ngayogyakarta not only lives and grows in the palace but also develop outside the palace of Yogyakarta since the era of Sultan Hamengku Buwono VII around 1918. This is thankdues to the idea of two sons of the Sultan namely Prince Tejokusumo and Prince Suryodiningrat, who founded an art organization called Krida Beksa Wirama. Since the presence of the organization, and subsequently, the emergence of other arts organizations, the classical dance of Yogyakarta style can be learned by ordinary people outside the palace (Hadi, 2013: 126).

\section{METHOD}

The research on the legitimacy of classical dance Gagrag or Ngayogyakarta (Yogyakarta) style, uses a qualitative method in 
which the researcher is the main instrument in the research process. Based on that approach, the researcher positioned himself as a participant observer, getting in as a participant in the community of the research subject that is the Yogyakarta palace.

The primary data collection is obtained through interviews with the informants, aimed at obtaining information and data from individuals in general for information purposes; while through respondents, the interviews aim to obtain information or specific information about the personal, attitudes, standpoints or views of the individuals interviewed for comparative purposes. In order to make non-contradicted interpretations, the researcher then conducted crosscheck of the information through a literature study. Most of the literatures are manuscripts, or chronicles in the Yogyakarta palace, especially those related to the research topic.

Observations and research on classical dance Yogyakarta style have been done for a long time; started from 2010 until now, by making research road-map starting from the classical dance performances developed both inside and outside the palace; and then analyze or identify its development, until the final goal is to analyze the revitalization of the dance. Therefore, this qualitative research, trying to clarify, to explain all data obtained, so that the results of the research is valid.

\section{RESULTS AND DISCUSSION}

One of the dances that have been legitimized as the cultural heritage of the Sultanate palace since the government of Sultan Hamengku Buwono I until now includes Beksan Lawung Gagah or Beksan Trunajaya. This dance was created by Sultan HB I himself, which becomes one of the characteristics of "Gagrag Ngayogyakarta". Until now, the dance is one of the pride of Yogyakarta palace, and has been made as a ceremonial dance as a symbol of personal representatives of the Sultan when he has a wedding ceremony of his sons and daughters in the reception of a royal wedding (Suryobrongto, 1981: 30-31). In traditional wedding ceremonies of the palace, this dance has a very high position, because it serves as a representative or on behalf of the Sultan. When the Sultan holds weddings of his sons and daughters, at the receptions or called lenggahan ageng, it is usually held in Bangsal Kepatihan. The Sultan himself did not attend the event, so the dance is a symbol of the legitimacy of the Sultan's presence, and brings the mandate to both the bride and groom, especially for having a new life, as well as the heroism messages, chivalry described in the dance. The group of Lawung Gagah dancers departed from the palace to Bangsal Kepatihan with the procession of horse riding with shaded by umbrellas, escorted by several corps of a warrior, train convoy accompanied by relatives of the Sultan, and along the way accompanied by Javanese gending karawitan. The dance form has specific characteristic or "style" indicated that it was created based on characteristics or the background of the creator, as well as the social background.

Beksan Lawung is a kind of strong male dance, so it is called "Lawung Gagah", which describes the practice of war using a lawung weapon or a kind of spear with dull ends. The creation of this dance was driven by a tradition of play called sabtonan, that is a war exercise performed by the soldiers on horseback, using weapons called lawung or watang, so it is often called watangan; which is done routinely on Saturdays, so it is called a sabtonan game (Kartodirdjo, et al., 1975: 249).

Lawung Gagah dance has a special characteristic or style of form and technique that is firm, solid, precise, fast, and masculine, following the nature and character of Sultan Hamengku Buwono I. Since he was 
with the title of Prince Mangkubumi, in his rebellion against VOC who stood with his nephew Susuhunan Pakubuwono III, and finally the VOC surrendered, and then made a Gianti agreement; Prince Mangkubumi is depicted as a strong figure, firm, strong determination, right and quick to make decisions to accept the contents of the agreement that Mataram kingdom was divided into two namely Surakarta, and Yogyakarta (Selo Soemardjan, 1986).

The dance is also called Beksan Trunajaya because it is inspired by the background of social-political situation at that time. The Sultan greatly admired the heroism of Trunajaya, a prince of Madura who persisted against Dutch colonialism in Java, so that the image reflected in the dance, wanted to instil a brave attitude against the enemy. Besides, the name of Trunajaya can also be suspected because, at that time, this dance was performed by a palace soldier named Corps Nyutra section of Trunajaya (Suryobrongto, 1981: 32). When it was still in a situation of upheaval against invaders, especially in Java many joined the soldiers from Madura and Bugis, so that the purpose of the dance creation is to arouse cou-

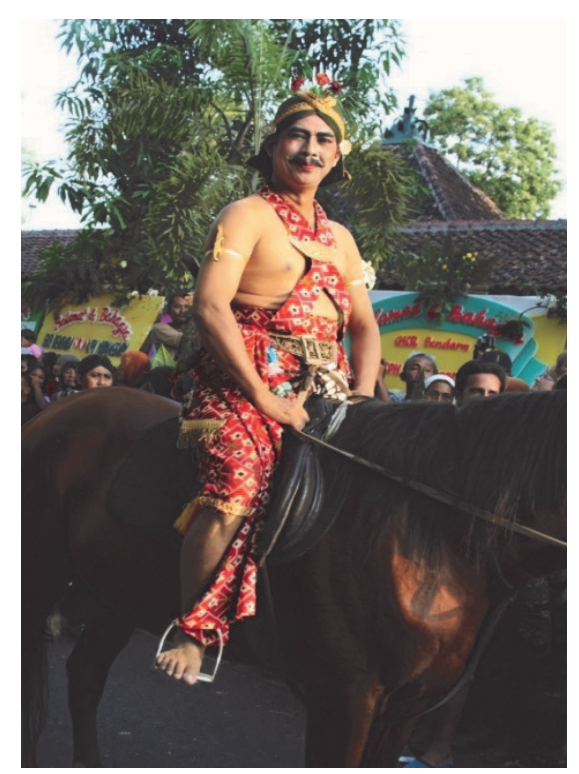

Image 1. One of Lawung Gagah dancers is riding a horse, from the palace to Bangsal Kepatihan (Dok.Foto: S. Hadi, 2011) rage, as well as to arouse the unity and fraternity of fellow warriors. Therefore, in the dances or Beksan Trunajaya, the inspiration of soldiers from Madura and Bugis areas, embodied in the expression of dialogue or pocapan in the dance.

In addition to Lawung Gagah dance as a dance, which is characterized by gagrag Ngayogyakarta, there is also Wayang Wong form and Bedaya dance. Sultan Hamengku Buwono I was also the first to introduce the type of Wayang Wong or dance drama gagrag Ngayogyakarta with a lot of dialogue or pocapan and loaded with the values of the contents of the story. At the first time, $\mathrm{Wa}$ yang Wong was created by Sultan Hamengku Buwono I with the story of Gandawerdaya, the story of carangan or composition taken from the epic of Mahabharata. Beside aesthetic purposes, creating the performing arts is also influenced by a social and political context. The gandawer's story of power is a depiction of the heroism of the ksatriya in the Mahabharata. This story actually depicts the history of Sultan Hamengku Buwono I himself during a dispute or conflict with his brother Sunan Paku Buwono II, and when it is always mediated by the Dutch with social, economic, and political interests that always harm the palace. In the play, it was told that the characters of ksatriya Gandawardaya and Gandakusuma are actually the same siblings of Ar-

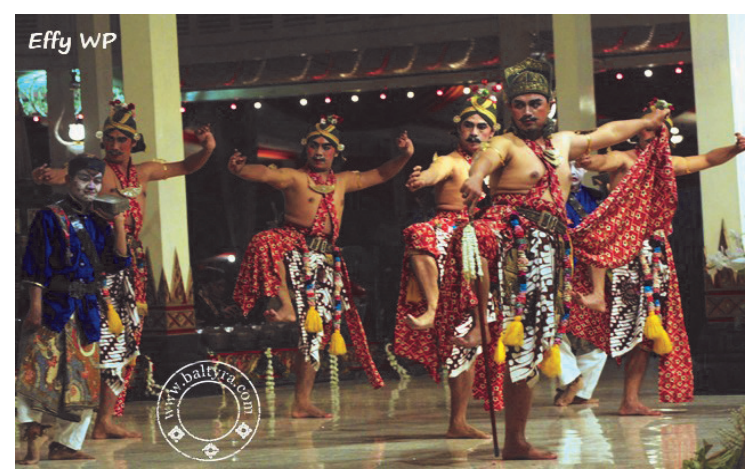

Image 2. Beksan Lawung Gagah was performed at Bangsal Kepatihan, Wedding ceremony of Sultan $\mathrm{HB} X$ (GKR Bendara) princess

(Dok. Foto: Effy WP, 2011) 
juna from a different mother; when both wanted to find their parents, and when the two brothers met then there was a conflict (Soedarsono, 2000: 33-58).

Another dance that became characteristics of gagrag Ngayogyakarta is Bedaya dance. If the Lawung Gagah dan Wayang Wong dance has more characteristic of a male or masculine character because it is danced by men; Bedaya dance is characterized by female characters. Although, at first, the Bedaya dance was performed by men (called Bedaya Kakung), who portrayed female characters or transgender, this dance was categorized as a female dance. It was because at that time, in the era of HB I - HB VIII, all female characters played by men who imitated women; women have not been allowed to perform in a dance performance.

This dance is performed by 9 dancers, each with its own character or role, symbolically representing the symbols of human limbs embodied in one of the floor patterns or Bedaya formations called "raft lanes" (see scheme). Dancer no.1 endhel pajeg; no. 2. Batak; no. 3. jangga symbolizes the "head" part; then dancer no. 4. dhadha,; no. 5. buntil symbolizes body or bloat; dancer no.6. apit ngajeng; and no. 7. wingking apit symbolizes the right hand and the left hand; while the second part of the foot denoted dancer no. 8. endhel wedalan ngajeng; and number 9. endel wedalan wingking dancers. Nine dancers are also often denoted by 9 holes that exist in perfect humans.

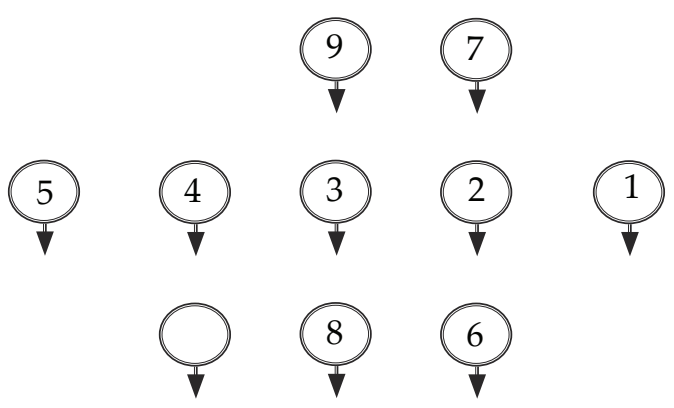

Schema: Floor pattern or dance formation of Bedaya Rakit Lajur

$=$ dancer direction

1 = Dancer endhel pajeg

2 = Dancer batak

3 = Dancer gulu

$4=$ Dancer dhadha

$5=$ Dancer buntil

$\begin{aligned} 6= & \text { Dancer apit ngajeng } \\ 7= & \text { Dancer apit wingking } \\ 8= & \text { Dancer endhel wedal- } \\ & \text { an ngajeng } \\ 9= & \text { Dancer endhel wedal } \\ & \text { an wingking }\end{aligned}$

The depiction of this dance is full of social values and norms, humanity, and has a dramatic type, so it contains themes following the contents of the story. For example, Bedaya Semang, which was created by Sultan Agung, and then continued by the Sultan HB I, considered as a Mataram heritage dance. The theme of the story depicts a mysterious, sacred encounter between his ancestor Panembahan Senopati and Ratu Kidul as the ruler of the southern sea. As the dance is considered a heritage dance of Mataram, it is categorized as a sacred dance, whose performances are only for certain ceremonies such as the anniversary commemoration.

The three types of dance performances are continuously preserved and developed by the Sultanate of Yogyakarta as a dance gagrag Ngayogyakarta; even it is considered as a dance of ancestral cultural heritage, to legitimize or validate the existence of the palace. Like Wayang Wong, Bedaya dance is performed for the anniversary of the Ascension of the Sultan or Pawiwahan Jumenangan Dalem. In fact, the dance functions as the king's greatness. The dance is equally aligned with other magical tools that have magical powers such as various weapons (spears, keris, swords, etc.), umbrellas of greatness, crowns, and other objects. The dances and those objects with their magical powers serve as "regalia", a kind of "heirlooms of the kingdom", which always guard and strengthen and provide protection, peace, welfare, the prosperity of the king, the state, and all of its people. Indeed, such beliefs have the meaning of the "cosmic" role of the king, the court and his government, that is the parallel between the 
understanding of "microcosm" and "macrocosm." In this case, the palace as a microcosm trying to find harmony, harmony, and harmony of life with the macrocosm, which is expecting sustainability to achieve welfare and the prosperity of the kingdom (von Heine-Gelden, 1982: 25).

Since the reign of Sultan Hamengku Buwono I until now, in the era of the Sultan Hamengku Buwono X, the continuity or sustainability of tradition to show Wayang Wong and Bedaya continue to perform. Each Sultan or jumeneng nata deliberately creates or performs such dances, which is not merely a matter of substantial contexts of performances but it functioned as an "authoritative" tradition or for a traditional ceremony. For example, Sultan Hamengku Buwono X created Bedhaya called Harjunawiwaha and used to perform Wayang Wong with Ciptaning Mintaraga or Harjunawiwaha. The story of Harjunawiwaha taken from the epic Mahabharata, and commonly called the Ciptaning Mintaraga story, which is essentially when Harjuna, the ksatriya from Pandawa, after defeating the giant king of Niwatakawaca enemies of the gods, he was given a gift of weapons and the princess Dewi Supraba. The story is symbolically performed in the Bedhaya dance, usually manifested in the final composition of the Bedhaya dance called the title raft. Dance Bedaya Harjunawiwaha once is staged for ritual customs of the palace, which is to commemorate the ascension of the throne or Pawiwahan Jumenengan Dalem Sultan Hamengku Buwono X, and birth anniversary or Pahargyan Tumbuk Ageng Sultan Hamengku Buwono X on 7 April 2007 (Hadi, 2013: 56). Then, Wayang Wong with Ciptaning Mintaraga story was once performed in Pagelaran Keraton Yogyakarta for the commemoration of the founding of Yogyakarta Sultanate palace or Pengetan Adeging Negari Dalem, in 2006. Such events were essentially functioning as the legiti-

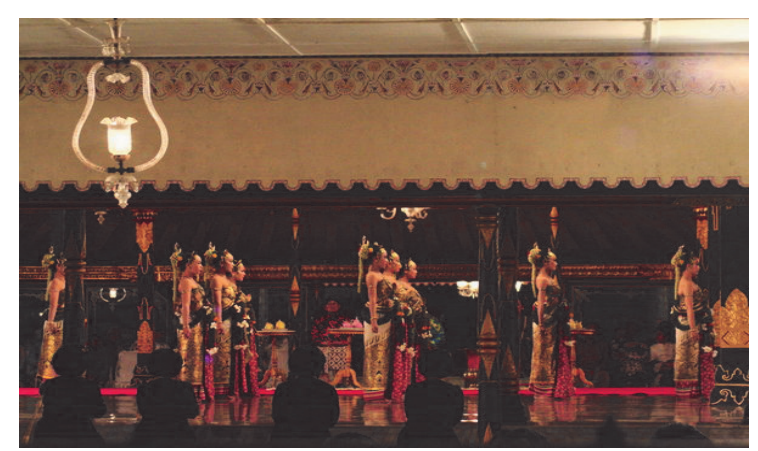

Image. 3. Bedhaya Harjunawiwaha in Rakit Kapangkapang majeng was performed at Bangsal Kencana, on Pahargyan Jumenengan Dalem, and Tumbuk AgengKelahiran Sultan HB X (Dok. Foto: Mashoeroel, 2007)

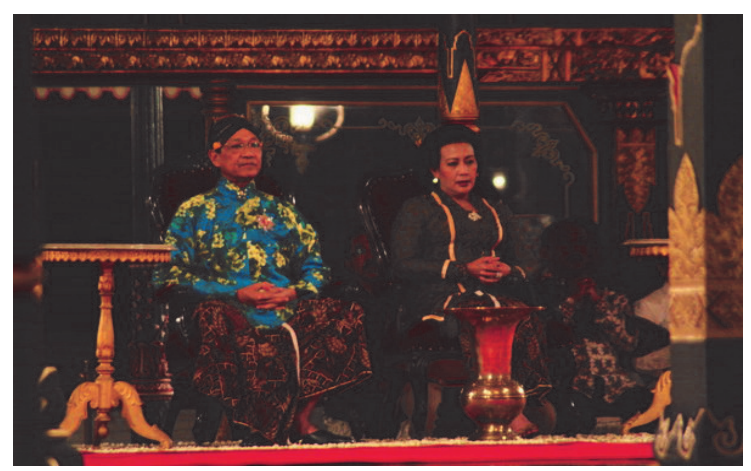

Image. 4. Sultan BH X and his wife GKR. Hemas on Pahargyan Jumenengan Dalem, and Tumbuk Ageng Kelahiran in 2007, were watching performance of Bedhaya Harjunawiwaha (Dok.Foto: Mashoeroel, 2007)

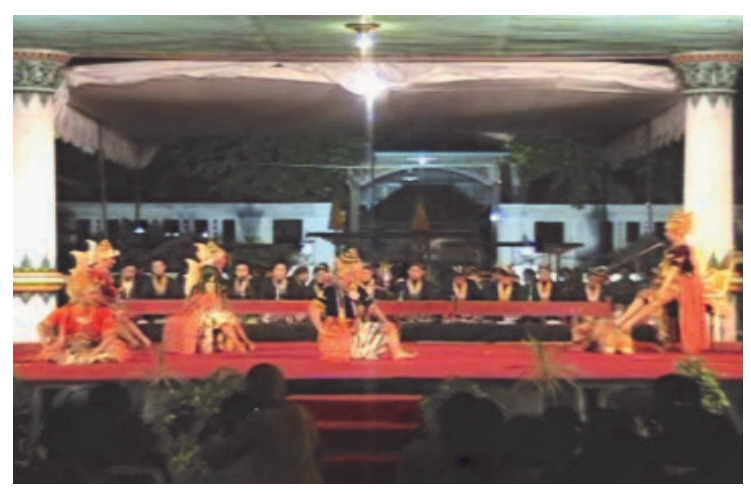

Image. 5 Wayang Wong performance with Cipataning Mintaraga at Pagelaran Keraton Yogyakarta, in commemoration of Keraton Kasultanan Yogyakarta (Dok. Foto: Y.S Hadi, 2006)

macy of Sultan's empowerment as king in Yogyakarta Sultanate.

In addition to the three dances of Beksan Lawung Gagah, Wayang Wong, and Bedaya, which become the pride of the palace, and considered as the source of all the dances 
in the Sultanate Palace of Yogyakarta, then evolved other types of dance that also became wealthy as a classical dance gagrag Ngayogyakarta. The types of dances include group dances such as Segara Guntur Segara, Beksan Etheng, Beksan Enjer Perangan, and solo dances such as Klana Raja Gagah, Klana Raja Alus, Golek Putri (Hadi, 2013: 69-89). The three dances of Beksan Lawung Gagah, Wayang Wong, and Bedaya, are often legitimized as sacred dances for the purposes of ritual ceremonies; while some of the latter dances are more secular.

The legitimacy of a classical dance $g a$ grag Ngayogyakarta since the reign of Sultan HB I until now continues to grow; beside preserving the dance and using it to legitimize what has been inherited from their ancestors, each sultan also has ideas to develop. Like Sultan HB IX, at the beginning of his reign around 1941, created a dance form known as the Beksan Golek Menak originating from the Menak or Menak Men Kit. This story came from Persian land, telling Hikayat Amir Hamzah (Uncle Prophet Muhammad). Along with the development of Islam in Java, the story was translated in Javanese to Serat Menak Amir Ambyah or Serat Menak Wong Agung Jayengrana (Poerbatjaraka and Hadidjaja, 1952: 123-126). The creation of the Golek Menak dance originated from the idea of Sultan after watching the Wayang show Golek Menak or Beksan Menak means to model or dance like a Wayang Golek Menak that was made of wooden dolls, played by a dalang. The Dance or Beksan Golek Menak was first staged at the palace for Tingalan Dalem in 1943, attended by nobles, regents, and other relatives of the palace (Kandha Serat and Serat Pocapan, Beksan Menak, Keraton Yogyakarta: Kridhamardawa, MS T. 56).

Beksan Golek Menak is a hallmark of the Yogyakarta palace style, which is not in the palace or any other palace. The dance since the reign of Sultan HB IX until now is still being developed and enhanced in the search for the motives. In 1987, the type of dance received special attention from the Sultan. On May 18, 1987, and on 29th - 30th December 1987, there was a meeting discussed about Beksan Menak, held in Jakarta, by bringing dance groups to exhibit their creations, such as from the Indonesian Art Institute of Yogyakarta, Siswo Among Beksa Yogyakarta Foundation, and Pencak Silat group from Padang (See Dinusatomo, 1987). In the workshop, Sultan HB IX himself was pleased to give suggestions, and comments, even giving examples of creations that need to be developed in the dance. (See Soedarsono, et al, 1989: 17-30). In the current administration of Sultan Hamengku Buwono X, the Pethilan Beksan Golek Menak also becomes the pride of the Yogyakarta court, includes Pethilan Beksan Golek Menak Adaninggar Kelaswara. This dance is about the battle between the Dewi Adaninggar of China against the Dewi Kelaswara because of jealousy of Adaninggar to Kelaswara who is successfully married by Amir Ambyah or Wong Agung Jayengrana, then ended with the defeat of Dewi Adaninggar. The dance is often performed mainly for entertainment purpose for the community, as well as show presentation for guests who visit the palace of Yogyakarta. The dance is usually performed with an eagle (burung garuda), which be-

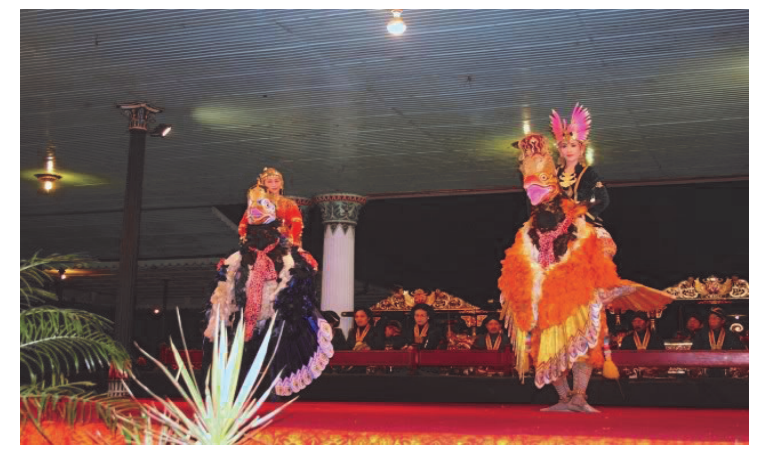

Image 6. Beksan Golek Menak Putri Dewi

Adaninggar (left) - Dewi Kelaswara (right); riding Garuda bird. The performance was in Keraton Yogyakarta (Dok. Foto: Mashoeroel, 2010) 


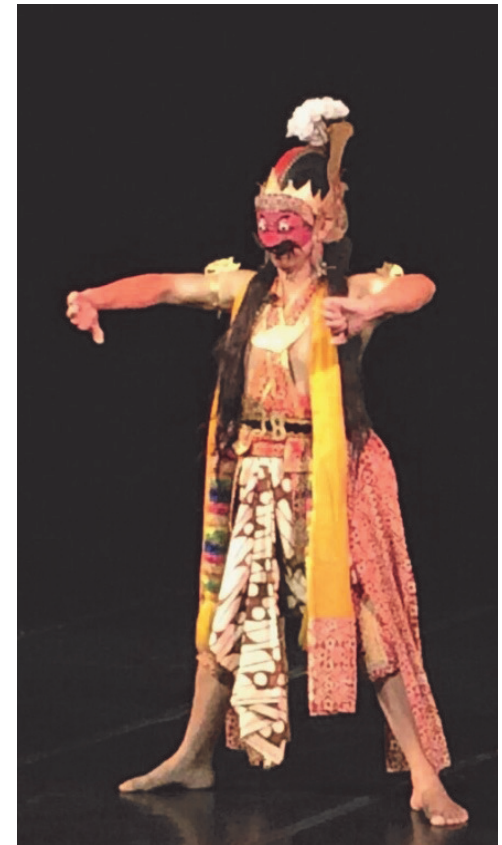

Image. 7. Klana Topeng Gagah or Klana Sewandana (Dok. Foto: Yudiaryani, 2016)

comes a symbol of the palace. The costume of this garuda character is unique which was created since the reign of Sultan Hamengku Buwono VIII (Hadi, 2013: 135-136).

In addition to dance or Beksan Golek Menak, Sultan Hamengku Buwono IX also permits the dance form called Klana Topeng, developed inside the palace. Klana Topeng is a single dance of both the types of the putra gagah (strong man) and the putra alus (soft man), it is a part of the dance drama or Wayang Topeng derived from the type of populist dance. Wayang Topeng is a kind of dance drama that brings the story of Panji, and all the dancers use masks or face masks made of wood. Part of the Wayang Topeng show called Klana Topeng Gagah depicts a figure called King Sewandana of the kingdom of Bantarangin, who travels (hence often called Klana Sewandana), and falls in love with Dewi Sekartaji or Candrakirana, the wife of Raden Panji. While Klana Topeng Alus depicts a character from the Panji story, a subtle character named Raden Gunungsari, the sister of Dewi Sekartaji, who is in love with Gandrung with the sis-

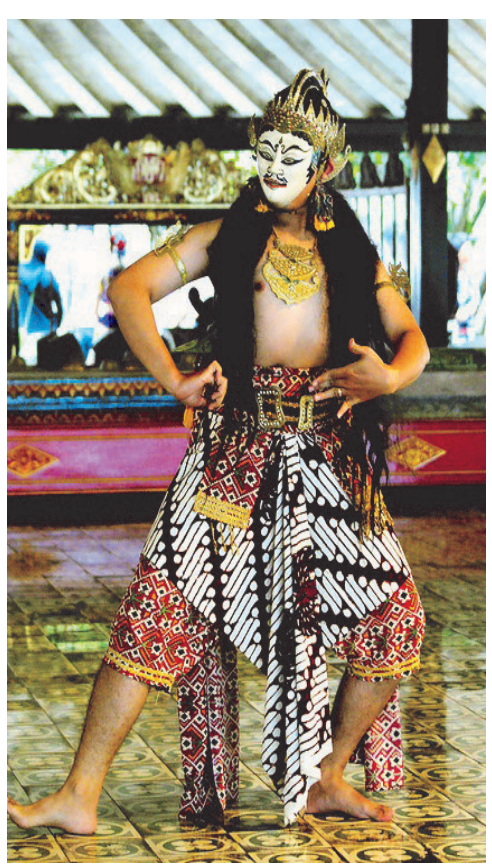

Image 8. Klana Topeng Alus or Klana Gunungsari (Dok. Foto: Agus Yuniarso, 2010)

ter of Onengan, sister Raden Panji. The two dances began to develop in the Yogyakarta palace around 1941 and had already been developed by one of Yogyakarta's classical dance organization Krida Beksa Wirama around 1938, led by two sons of Sultan HB VII, namely Prince Tejokusumo and Prince Suryodiningrat. Through an organization that developed outside the palace, and also got support from the palace, then this type of Klana Topeng dance can develop also inside the palace. Two types of dance, Beksan Menak and Klana Topeng that belong to the secular type of dance, have been legitimized as a classical dance gagrag Ngayogyakarta that continues to be preserved and developed.

\section{CONCLUSION}

Legitimacy or legalization of classical dance Gagrag Ngayogyakarta as a traditional cultural heritage has fairly strong historical roots, as it gets the support of the Sultanate Palace Ngayogyakarta Hadiningrat. The institutionalization began after Gianti Agreement in 1755, a regional political agree- 
ment, as well as a cultural treaty, when the New Mataram kingdom was broken into two palaces, namely Ngayogyakarta Hadiningrat Sultanate and Surakarta Hadiningrat Sultanate Palace. Keraton Kasultanan Ngayogyakarta under Sultan Hamengku Buwono I, until the successive Sultan who is now entitled Sultan Hamengku Buwono $\mathrm{X}$, is considered as one of the legitimated classical art and cultural centre, in addition to Keraton Kasunanan Surakarta.

Since then, Gagrag Ngayogyakarta classical dance, which developed inside the palace, is an art that has standards or rules applied strictly. Classical dance Gagrag Ngayogyakarta reinforces his standardization as a noble dance, based on the philosophical foundations called "Kawruh Joged Mataram" which is the art of inspiration for a dancer consisting of four main elements called sawiji, greged, sengguh, and ora ming$k u h$, and the rule is practically the aesthetic concepts called wiraga, wirama, and wirasa.

Various types of classical Gagrag Ngayogyakarta dance that developed until now can be divided into two categories, namely the types of sacred dance that is functioned for traditional ceremonies or rituals, and secular dance for entertainment purpose or spectacle for guests and tourists who visited the palace of Yogyakarta. The classic Gagrag Ngayogyakarta dance, that has been created since the reign of Sultan Hamengku Buwono I include Beksan Lawung Gagah or Beksan Trunajaya, Wayang Wong and Bedaya, is considered as the main source of the creation of other dances.

Since the reign of Sultan Hamengku Buwono I in 1756-1792 until now (Sultan Hamengku Buwono X, since 1989), each Sultan has a tradition of performing Beksan Lawung Gagah, Wayang Wong, and Bedaya dances. Performances in various ritual ceremonies, such as the anniversary commemoration of the throne, actually serve as a legitimacy of the inauguration of Sultan's authority as a king in the Sultanate of Yogyakarta. In addition to legitimize certain performances, every Sultan who is on the throne also has a tradition of creating $\mathrm{Be}$ daya dance which is considered as one of the dances filled with philosophical values of humanity, as showing in the example of Sultan Hamengku Buwono $X$ who reigns today. He created Bedaya Harjunawiwaha and Bedaya Sang Amurwabumi.

The type of dance, both sacred and secular, has been legitimated as a classical dance Gagrag Ngayogyakarta. Yogyakarta Palace also recorded its own history to develop the type of dance Klana Topeng as part of the Wayang Topeng derived from the popular dance and created a dance called Beksan Golek Menak. Both types of dance are also legitimized as classical dance Gagrag Ngayogyakarta. The Beksan Golek Menak, that is created by Sultan Hamengku Buwono IX in 1941, until now becomes a unique characteristic or dance style of the palace of Yogyakarta.

\section{Bibliography}

GBPH Suryobrongto

1981 "Sejarah Tari Klasik Gaya Yogyakarta", dalam Fred Wibowo, (ed)., Mengenal Tari Klasik Gaya Yogyakarta. Yogyakarta: Dewan Kesenian Prop. DIY.

1981 “Penjiwaan dalam Tari Klasik Gaya Yogyakarta" dalam Fred Wibowo, (ed)., Mengenal Tari Klasik Gaya Yogyakarta. Yogyakarta: Dewan Kesenian Prop. DIY.

Heine-Gelden, Robert von

1982 Konsepsi Tentang Negara dan Kedudukan Raja di Asia Tenggara, Translation. Deliar Noer. Jakarta: Rajawali. 
Kridhamardawa, MS.

tt. Serat Kandha and Serat Pocapan Beksan Menak, Keraton Yogyakarta: Kridhamardawa, MS. T. 56.

Poerbatjaraka dan Tardjan Hadidjaja

1952 Kepustakaan Djawa. Djakarta: Djambatan.

R.M Dinusatomo

1987 “Tari Golek Menak di Daerah Yogyakarta" dalam Makalah Sarasehan Beksan Menak, Jakarta, 18 Mei 1987.

Sartono Kartodirdjo, dkk.

1975 Sejarah Nasional Indonesia Jilid III. Jakarta: Dep. P dan K.

Selo Soemardjan

1986 Perubahan Sosial di Yogyakarta. Yogyakarta: Gadjah Mada University Press.
Soedarsono, dkk.

1989 Sultan Hamengku Buwono IX Pengembang dan Pembaharu Tari Jawa Gaya Yogyakarta. Yogyakarta: Prop. DIY.

2000 Masa Gemilang dan Memudar Wayang Wong gaya Yogyakarta. Yogyakarta: Tarawang.

Y. Sumandiyo Hadi

2013 Tari Klasik Gaya Yogyakarta: Legitimasi Warisan Budaya.Yogyakarta: Lembah Manah.

2013 “Kontinyuitas dan Perkembangan Tari Klasik Gaya Yogyakarta sebagai Warisan Budaya", in Journal Mudra, Vol. 28, No. 1 Januari 2013, Denpasar: ISI Denpasar, UPT. PePenerbitan. 